UNTAG Law Review (ULREV)

Volume 3, Issue 1, May 2019, PP 88-102

ISSN 2549-4910 (online) \& ISSN 2579-5279 (print)

http://jurnal.untagsmg.ac.id/indeks.php/ulrev/indeks

www.fakhukum.untagsmg.ac.id

\title{
EXISTENCE OF TERAPEUTIC AGREEMENTS AS BASICS OF RELATIONSHIP DOCTORS AND PATIENTS IN HEALTH SERVICES
}

\author{
Prof. Dr. Sarsintorini Putra, SH.,MH \\ Faculty of Law UNTAG Semarang, \\ Email :sarsintorini44@gmail.com
}

Anggraeni Endah Kusumaningrum

Faculty of Law UNTAG Semarang

Email : anggraeniwijayanto@yahoo.com

\begin{abstract}
This work aims to analyze the existence of a therapeutic agreement as the basis of the relationship between doctors and patients in health services. Health services originate from a relationship of trust between doctors and patients that develops into a therapeutic transaction or therapeutic agreement. The object of this therapeutic agreement, when viewed from medical science, can be specified in general in health services that can be started from promotive, preventive, curative, and rehabilitative efforts. Juridically, all medical action in the health service can be a legitimate object of law, but the form of the medical agreement must be clear whether the inspector is an agent (agreement on the effort) or result of the intervention (agreement on results). This is important in relation to the burden of proof in the event of a lawsuit.
\end{abstract}

Keywords: Existence; Therapeutic Agreement; Doctor and patient.

\section{INTRODUCTION}

Improving quality standards in accordance with applicable service standards in health services (medical) is important and must be maintained, so that the community can feel the services provided. Service in essence is an effort to help everything that is needed by others so that it can provide satisfaction in accordance with the wishes expected by consumers. There are three components in the service process that are mutually influential namely, the quality of services provided, who does the service, and consumers who value a service through the expectations they want. ${ }^{1}$

1 Titik Triwulan Tutik, Perlindungan Hukum Bagi Pasien, Prestasi Pustaka Publisher, Jakarta, 2010,page.12. 
The 1945 Constitution of the Republic of Indonesia, especially Article 28H paragraph (1) reads: "Every person has the right to live in physical and spiritual prosperity, to live and get a good and healthy environment and to receive health services," and Article 34 paragraph (3) reads: "The state is responsible for providing adequate health care facilities and public service facilities". Based on this, it means that the right of every citizen to get health and life services that are healthy, health is a human right to achieve a prosperous life both birth, mind and social. WHO provides an ideal definition of health, namely: "... A state of complete physical, mental, and social well being not only the absence of disease of infirmity ", which means as follows:" Healthy state (status) is intact physically, mentally (spiritually) and socially, and not just a condition free from diseases, disabilities and weaknesses ... ". ${ }^{2}$

In Law Number 36 of 2009 concerning Health in Article 1 paragraph (1) stipulates that: "Health is a healthy condition, both physically, mentally, spiritually and socially which enables everyone to live productively socially and economical". A person who seeks health efforts will come to the person who is considered able to restore or treat his disturbed health. Doctors are considered able to cure the patient's illness. Health services originate from a relationship of trust between doctors and patients which in its development is often referred to as a therapeutic transaction or therapeutic agreement, which means a transaction or agreement to determine therapy or provide the most appropriate healing services for patients by a doctor. The relationship between a doctor and a patient contained in a therapeutic agreement raises the existence of rights and obligations for both. ${ }^{3}$

Endang Kusuma Astuti argues that in therapeutic transactions, that becomes object is an attempt at healing. This is often misunderstood by ordinary people that the recovery of patients who become the object of therapeutic transactions. Even though the transaction object Therapeutic is the doctor's effort in treating patients, not the patient's recovery because if the patient's recovery is made into an object, it will corner the doctor more. ${ }^{4}$ Health efforts in therapeutic transactions between doctors and patients include 4 (four) health efforts, namely: ${ }^{5}$

1. Promotive efforts (efforts to improve health);

2. Preventive efforts (prevention efforts);

3. Curative efforts (healing/treatment efforts);

2 Munandar Wahyudin Suganda, Hukum Kedokteran, Alfabeta, Bandung, 2017, page. 11

3 Anggraeni Endah Kusumaningrum, Tinjauan Yuridis Hak dan Kewajiban Pasien Sebagai KonsumenDalam Pelayanan Medis, Supremasi Hukum, Vol. 2 No. 1, Fakultas Hukum Universitas 17 Agustus 1945,Semarang, Juni 2013, page. 3

4 Endang Kusuma Astuti, Transaksi Terapeutik Dalam Upaya Pelayanan Media Di Rumah Sakit, Citra Aditya Bakti, Bandung, 2009, page.97

5 Munandar Wahyudin Suganda, op.cit., page. 52 


\section{Rehabilitative efforts (recovery efforts).}

Health efforts above are influenced by socio-cultural environmental factors, including economic, physical and biological environments that are dynamic and complex, realizing how widespread it is, the government through the national health system, seeks to organize national health that is comprehensive, integrated, equitable and can be accepted and affordable by all levels of society. The effort was held by focusing on health services for the wider community, in order to achieve optimal health status.

Health Act Number 36 of 2009 Article 1 paragraph (3) states that "Health efforts are every activity and / or series of activities carried out in an integrated and sustainable integrated manner to maintain and improve public health degrees in the form of disease prevention, health improvement, treatment of diseases, and health recovery by the government and / or the community ". Then in Article 1 paragraph (12) it is stated that: "Promotive health services are activities and / or a series of health service activities that prioritize activities that are health promotion in nature". Furthermore Article 1 paragraph (13) of the Health Act Number 36 of 2009 states that: "Preventive health services are an activity to prevent a health problem". Then Article 1 paragraph (14) states that: "Curative health services are activities and / or a series of medical activities aimed at healing diseases, reducing suffering due to disease, disease control, or controlling disability so that the quality of patients can be maintained optimally", and Article 1 paragraph (15) states that: "Rehabilitative health services are activities and / or a series of activities to return sufferers to the community so that they can function as members of the community that are useful for themselves and the community as much as possible according to their abilities".

The object of medical agreement when viewed from the point of view of medical science, it can be detailed through common efforts in a health service that can be started from promotive, preventive, curative, and rehabilitative efforts. Based on this, the variation of the treaty object can be a medical check-up, immunization, family planning; efforts to cure disease, alleviate suffering, prolong life, and rehabilitate. ${ }^{6}$

Juridically all medical measures mentioned above can be legal objects of the law, but the form of the medical agreement must be clear whether the inspector is the type (agreement on effort) or resultaatverbintenis (agreement on results). This is important in relation to the burden of proof in the event of a lawsuit. However, if the doctor works according to his professional standards and there is no element of negligence, it does not need to worry.

6 Ibid., page. 53 and 54 


\section{Formulation of the Problem}

Based on the background above, the formulation of the problem in this paper Is the existence of a therapeutic agreement as the basis of the relationship between doctors and patients in health services?

\section{Discussion}

The relationship between doctor and patient begins with a paternalistic vertical pattern such as between a father and his child that departs from the principle of "father know best" (the father knows what is best for his child) which gives birth to a paternalistic relationship.

In the pattern of paternalistic vertical relations the position between doctors and patients is not equal, namely the position of the doctor is higher than the patient because the doctor is considered know about everything related to illness and its healing, while the patient knows nothing about the disease so the patient submits it his fate is entirely in the hands of the doctor.

In this paternalistic vertical relationship pattern there are positive and negative impacts. The positive impact is to help patients who are unfamiliar with the disease. On the contrary, the negative impact is if the act of healing the patient is an act of the doctor who limits the autonomy of the patient who in the history of cultural development and basic rights (human rights) already exists. In accordance with the times, the relationship between doctors and patients experienced a shift in the pattern of relationships that initially vertical paternalistic became horizontal contractual. The pattern of contractual horizontal relations is the legal relationship between doctors and patients who are equal or equal who respect the rights and obligations of the parties between the doctors and patients. Relationships that occur between doctors and patients will eventually lead to legal relationships in the form of agreements or referred to as therapeutic agreements, namely a transaction between doctors and patients where each party must meet the requirements in the rule of law. ${ }^{7}$ Therapeutic agreements are agreements between doctors and patients, in the form of relationships law which gives birth to rights and obligations for both parties. Unlike transactions commonly carried out by the community, therapeutic transactions have characteristics or characteristics special ones that are different from the agreement in general, specifically located at or regarding the promised object. The object of the therapeutic agreement is an effort or therapy for healing patients. So a therapeutic agreement is a transaction for or efforts to find the most appropriate therapy for patients performed by doctors. So according to the law, the object of agreement in a therapeutic transaction is not the recovery of the patient, but rather seeking the right effort to cure the patient. $^{8}$

7 Anggraeni Endah Kusumaningrum, Penerapan Hak dan Kewajiban Pasien Sebagai Konsumen Dalam Pelayanan Medis, Fakultas Hukum Universitas 17 Agustus 1945, Semarang, page. 7

8 Bander Johan Nasution, Hukum Kesehatan Pertanggungjawaban Dokter, Rineka Cipta, Jakarta, 2013,page. 11 
In the therapeutic transaction the law of engagement also applies because there are parties who bind themselves in an agreement or agreement. According to Subekti an agreement is an event that someone promises to do something. Terms of the validity of an agreement as stipulated in Article 1320 of the Civil Code whose elements are as follows: ${ }^{9}$

1. There is an agreement from those who tie themselves to each other (toesteming van degenen die zichverbinden);

2. The ability to make an agreement (debekwaamheid om eene verbintenis aan to gaan);

3. Regarding certain things (een bepaald onderwerp);

4. Areason that is allowed (eene geoorloofdeoorzaak).

The first and second elements are referred to as subjective elements because these two elements directly involve the person or subject making the agreement. If one of the subjective conditions is not met, then the agreement at the request of the party concerned can be canceled by the judge. The intention is that the agreement as long as it has not been canceled remains valid, so there must be a judge's decision to cancel the agreement. Cancellations take effect from the judge's decision to obtain permanent legal force, so the agreement is canceled not from the beginning or since the agreement was made. The third and fourth element is called the objective element, it is said to be because the two elements are related to the object promised. If one of these elements is not fulfilled, the agreement at the request of the party concerned or ex officio in the judge's decision can be declared null and void, then the agreement is declared null and void, so that the agreement is deemed to have never existed. So the cancellation was from the beginning. The legal consequences for the parties, the position of the two parties was returned to their original position before the agreement was made.

Every party that enters into an agreement must know and obey the principles of the agreement. Agreement principles are the moral and ethical foundation in making agreements. The principles of the agreement are: ${ }^{10}$

1. The principle of freedom enters into an agreement / principle of freedom of contract (autonomy); This principle of freedom of contract and the principle of binding power are contained in Article 1338 paragraph (1) of the Civil Code. This provision reads: "All agreements made legally apply as laws for those who make them".

2. Principle of consensualism (conformity of will);

"Agree that those who bind themselves" is the essential principle of the treaty law. This principle is also called the "consensualism" autonomy principle which determines the

9 Ibid., page. 12

10 Munandar Wahyudin Suganda, op.cit., page. 58-62 
existence (raison d'etre, het hestaanwaarde) of this agreement. It can be found in Article 1320 and Article 1338 of the Civil Code. In Article 1320 the Civil Code of the denominator is firm, while in Article 1338 the Civil Code is found in the term "all". All words indicate that each person is given the opportunity to express his will (will), which is felt to be good for creating an agreement. The principle of consensualism is very closely related to the principle of freedom of agreement.

3. Principle of trust;

Someone who enters into an agreement with another party, fosters trust between the two parties that each other will hold their promise, in other words it will fulfill its performance behind the day without that trust, then the agreement will not be held by the parties. With this belief, both parties bind themselves and for both the agreement has binding power as a law.

4. The principle of binding power;

The binding of the parties to the agreement is not only limited to what is agreed upon, but also to several other elements as long as it is desired by habit and propriety and morals.

5. The principle of equality of law;

This principle places the parties in equality, there is no difference, even though there are differences in skin, nation, wealth, power, position and others. Each party must see this equality and require both parties to respect each other as human beings created by God.

6. Principle of balance;

This principle requires both parties to fulfill and implement the agreement. This principle of balance is a continuation of the principle of equality. Creditors have the power to demand achievements and if needed can demand repayment of achievements through the debtor's wealth, but creditors also bear the burden of implementing the agreement in good faith. It can be seen here that the position of a strong creditor is balanced with its obligation to pay attention to good faith, so that the position of creditors and debtors is balanced.

7. Principle of legal certainty;

The agreement as a legal figure must contain legal certainty. This certainty was revealed from the power of binding the agreement, namely as a law for the parties.

8. Moral principle;

This principle is seen in a reasonable agreement, where a voluntary act from a person does not give him the right to sue the counter-performance of the debtor. Also this is seen in zaakwarneming, where a person who commits a voluntary (moral) act concerned has an 
obligation (law) to continue and complete his actions as well as this principle is contained in Article 1339 of the Civil Code. Factors that give motivation to the person involved in carrying out legal actions are based on "morality", as a call from his conscience.

9. The principle of propriety;

This principle is set forth in Article 1339 of the Civil Code, the principle of decency here relates to the provisions concerning the contents of the agreement. This principle of propriety must be maintained, because through this principle the measure of relations is also determined by a sense of justice in society.

10. Habit principle.

This principle is regulated in Article 1339 and Article 1347 of the Civil Code, which are seen as part of the agreement. An agreement is not only binding on what is explicitly regulated, but also things that are in the circumstances and habits commonly followed. According to Article 1339 of the Civil Code, the agreement is not only binding on matters expressly stated in it, but also for everything that according to the nature of the agreement, is required by propriety, customs and law. Article 1347 of the Civil Code also says that things which, according to the custom of being forever promised (bestending gebruikelijk) are considered secretly included in the agreement even though they are not expressly stated.

In the agreement as stipulated in the Civil Code Book III concerning Engagement, known there are 2 (two) types of agreements, namely: ${ }^{11}$

1. Inspanningverbintenis, namely an agreement of effort, meaning that both parties promise to make maximum effort to realize what is promised;

2. Resultaatverbintesis, namely an agreement that the party that promises will give a result, which is the real result in accordance with what was promised.

Veronica Komalawati argues that because therapeutic transactions constitute a legal relationship between doctors and patients, several legal principles that underlie or are contained in the various underlying rules apply, namely: ${ }^{12}$

\section{Principle of legality;}

The legality principle in Law Number 36 Year 2009 is written from the provisions of Article 23 paragraph (1), paragraph (2), paragraph (3), paragraph (4), and paragraph (5). This means that medical services can only be carried out if the health personnel concerned

11 Bander Johan Nasution, op.cit., page. 13.

12 Veronica Komalawati, Peranan Informed Consent Dalam Transaksi Terapeutik, Citra Aditya Bakti,Bandung, 1999, page. 126-130 
have fulfilled the requirements and permits regulated in the legislation. Law No. 36 of 2009 also provides legal protection for doctors and health workers who carry out tasks in accordance with their profession (Article 27 paragraph (1)).

\section{Principle of balance;}

Article 2 of Law Number 36 of 2009 states: "Health development is carried out based on humanity, balance, benefits, protection, respect, rights and obligations, justice, gender and non-discrimination and religious norms" According to this principle of balance that health development must be carried out in a balanced manner between individual and community interests, between physical and mental, and between material and spiritual. In medical services can be interpreted as a balance between goals and means, between facilities and results and between benefits and risks arising from medical efforts carried out.

\section{The principle is timely;}

This principle is very necessary because due to negligence in giving help just when it is needed, it can cause harm to the patient. In connection with that in Article 32 of Law Number 36 of 2009. Article 32 paragraph (1) reads: "In an emergency, health service facilities, both government and private, are obliged to provide health services for saving patients' lives and preventing disability first. ", While Article 32 paragraph (2) reads:" In an emergency, health service facilities, both government and private, are prohibited from rejecting patients and / or asking for advances ". Doctors as professionals in the medical field should be able to act precisely when needed. Based on this principle, an action that must be carried out immediately in the context of medical services, for the sake of the patient cannot be postponed solely for the personal benefit of the doctor.

\section{Principle of good faith.}

Therapeutic agreement is essentially an engagement between doctors as health care workers and patients who need health care efforts. In Article 1338 the Civil Code states that: "An agreement must be carried out in good faith (goede trouw)".

In the therapeutic agreement, it will create rights and obligations between the doctor and the patient. Doctors have responsibility for individuals and families, in addition to their professional responsibility to society, therefore doctors have rights and obligations.

\section{The doctor's obligation is:}

a. Have a practice permit; The obligation to have a practice permit in a health service place is the first obligation that must be owned by a doctor as stipulated in Article 36 of Act Number 29 of 2004 concerning Medical Practice. A practice permit is obtained by a doctor from the 
district / city health office after obtaining recommendations from professional organizations.

The condition for getting recommendations from professional organizations is if a doctor has been registered by the Indonesian Medical Council (KKI) after registering and passing a doctor's education (getting a diploma). Procedures for registering to obtain a Registration Certificate (STR) and Practice License (SIP) are regulated in Permenkes: Number 2052 / Menkes / Per / X / 2011 concerning Permit for Practice and Implementation of Medical Practices.

To protect patients' rights to obtain services by capable doctors, the law provides sanctions for doctors who do not have a Registration Certificate and Practice License that serves medical practice (Article 75 and Article 76 of Act Number 29 of 2004).

b. Carry out professional standards, service standards and standard operating procedures; All of that as a form of achievement in the agreement made by doctors with patients in order to carry out medical practice. This is regulated in Article 39 of Law Number 29 of 2004. So if after the agreement and the passage of therapeutic transactions occur, it is the duty of the doctor to always adhere to the standardization mentioned above, so that if the standards deviate and cause harm to patient, the patient is entitled to compensation for the loss.

c. Obligation to introduce identity;

Identity in this case is an independent practice board or signboard for doctors who work in health facilities / hospitals. It is the patient's right to obtain information with / to whom he is treated, the type of doctor's expertise, doctor's practice permit and schedule of visits (Article 41 paragraph (1) and paragraph (2) of Law Number 29 Year 2004).

d. Approval of medical action;

Informed consent is regulated in Article 45 paragraph (1) and paragraph (2) of Law Number 29 of 2004. Every action that will be taken by a doctor must get the consent of the patient both written and oral. In applying this obligation, in addition to giving patients approval for medical action, patients can reject some or all of the actions recommended by the doctor.

e. Carry out informed consent;

Approval of medical action must be preceded by an explanation called the informed consent according to what is regulated by Article 43 paragraph (3) of Law Number 29 of 2004. 
f. Making medical records;

The next obligation is to make a medical record after conducting an examination, treatment, or action in the form of a medical record. This obligation is stated in Article 46 paragraph (1) of Law Number 29 of 2004 which reads: "Every doctor or dentist in carrying out medical practice is obliged to make a medical record".

g. Maintain medical secrets;

Everything doctors know about patients related to patients' health problems is the secret of patients entrusted to doctors, so doctors must take care of them as long as patients do not want to be opened unless permitted by law. This secret needs to be maintained even after the patient dies (Article 48 paragraph (1) and paragraph (2) of Law Number 29 Year 2004).

h. Quality and cost control;

This is the duty of the doctor, so that patients always get the best service. Always conduct audits both internally and externally. This obligation is contained in Article 49 paragraph (1) of Law Number 29 of 2009 which reads: "Every doctor or dentist in carrying out medical or dental practices must carry out quality control and cost control".

i. Refer patients;

Patients are entitled to the best health services, so that when the condition of a doctor is unable to handle the patient, then he must refer patients to facilities or other doctors who are considered capable (Article 51 letter b of Law Number 24 Year 2004).

j. Perform emergency assistance on the basis of humanity;

Giving this assistance is carried out if there is an emergency or emergency and there is no other person (other doctor) who is in that location. This rule is regulated in Article 51 letter (d) of Law Number 24 of 2009 which reads: "Conducting emergency assistance on the basis of humanity, except if he believes someone else is on duty and able to do so".

k. Add knowledge and keep up with the development of the medical world.

Every minute there has always been a change in previous knowledge, including in the medical world both about changes in theory, treatment and action. If a doctor is not always up to date on the development of science, then he will stay with the latest treatment methods and if he still uses the old method, while it is no longer recommended, then if there is a loss suffered by the patient due to the old method, then the patient has the right to sue or sue the doctor who is careless by not following the development of knowledge (Article 51 letter (e) of Law Number 24 of 2004). 


\section{The right of the doctor is:}

A doctor in a therapeutic agreement other than an obligation, but also has the right of the doctor as is usually an agreement. Certain rights for doctors, namely ${ }^{13}$ :

a. The right to work in accordance with medical professional standards;

b. The right to refuse to take medical action that is contrary to his conscience;

c. The right to refuse to take medical actions that cannot be accounted for professionally;

d. The right to choose patients;

e. The right to terminate relations with patients if cooperation is no longer possible;

f. The right to privacy;

g. The right to good faith from the patient in providing information relating to his illness;

h. The right to a "fair play";

i. The right to self-defense;

j. The right to receive an honorarium;

k. Hak refused to testify about his patients in court.

The most important right of the doctor is the right to work according to the standard of his profession. Doctors have a professional freedom but do not have freedom Therapeutic. Although doctors have the freedom to choose certain medical methods and consider alternative possibilities, they will but the decision to use the method is in the hands of the patient. So freedom therapeutic is on the patient's side and there is freedom from patients and doctors to discuss together everything about the cooperative relationship or medical agreement.

While the patients who carry out therapeutic transactions with doctors, patients who make agreements with doctors also have the rights and obligations of patients.

\section{The patient's rights are:}

Dany Wiradharma believes that patient rights can be mentioned as follows: ${ }^{14}$

a. Right to choose patients;

Because the relationship between doctors and patients is mainly based on trust, generally patients always choose to go to a particular doctor. But the right to choose this doctor is

13 Danny Wiradharma, Hukum Kedokteran, Binarupa Aksara, Jakarta, 1996, page. 82 and 83

14 Ibid., page. 68-71 
relative, especially for employees of a company that already has a company doctor or a company doctor.

b. Right to choose health facilities;

Patients also have the right to choose hospitals within certain limits. Usually the hospital chosen by the patient is a hospital that prioritizes good care services, in addition to the completeness of medical equipment. Even so patients usually prefer doctors who will treat them compared to hospitals with all the equipment / services. Therefore the "best-selling" doctor is expected by the hospital to practice at the hospital.

c. The right to refuse treatment/ treatment;

Doctors may not force people who refuse to be treated, unless it will disrupt the public interest or endanger other people, for example in patients who suffer from mental disorders.

d. The right to reject certain medical actions;

If the patient rejects a medical action that is needed in the framework of diagnosis or therapy, even though the doctor has provided a full explanation before the doctor cannot do it. It is better for the patient to be asked to make a statement rejecting the medical action.

e. The right to stop treatment/ care;

The reason for discontinuing treatment / treatment can be due to economic difficulties or because it is of no use for the healing process. For this reason, patients are asked to make a statement of termination of treatment based on their own wishes.

f. Right to second opinion/ second opinion;

The patient has the right to get an explanation from another doctor who is equal to the doctor's qualifications regarding the disease and this is ideally done with the knowledge of the first doctor who treated him.

g. "Inzage" medical record rights;

The legal provisions state that the medical record file belongs to the hospital (for good administration) while the information data / or its contents belong to the patient because it comes from the patient. Therefore, the patient has the right to know or examine the medical record or make a copy of it (at the applicant's expense).

h. The right to worship;

Each patient has the right to worship as long as it is possible according to the condition of his illness and does not disturb patients or visitors to the hospital. 


\section{The patient's obligations are:}

As a balance to the rights of the patient, the patient also has burden of obligations. Because in essence the balance of rights and obligations is a measure of a sense of justice towards oneself. Some patient obligations are as follows: ${ }^{15}$

a. Obligation to provide information;

Medical information obtained through interviews or history is one of the main elements in the enforcement of a diagnosis of a patient's disease and this diagnosis is very important to determine a medical action. If the patient intentionally hides information or provides false information and then an injury arises, the doctor can be released from the mistake. This is also very closely related to what is called "good faith" of these patients.

b. Obligation to obey doctor's instructions or advice.

This obligation is important because it is directly related to the success of medical actions taken by the doctor. As well as the obligation to provide medical information. All consequences arising from not fulfilling the doctor's instructions or advice, of course regardless of the responsibility of the doctor who treats it. In addition, the doctor also has the right to cut off the doctor's professional relationship with the patient if it is judged that the collaboration between the patient and the doctor is of no use anymore.

c. Obligation to fulfill the rules on health facilities.

In this case, including the obligation to complete administration, finance, and so on. Also includes things about visiting hours, patient watchers, foods that may or may not be, and others.

d. Obligation to provide compensation for services to doctors.

This obligation needs to be enforced to achieve legal equality in the relationship of doctors and patients where all the work of the doctor must be properly valued, insofar as the patient's condition allows.

e. The obligation to be honest;

If during a doctor's or hospital's care a problem arises, for example the patient is not satisfied with the treatment or treatment provided, the patient is obliged to submit it to the treating physician first.

15 M. Achadiat Crisdiono, Pernik-Pernik Hukum Kedokteran, Melindungi Pasien dan Dokter, Widya Medika, Jakarta, 1996, page. 79 
f. Obligation to convey known doctor's personal secrets.

Obligations are actually parallels with the patient's right to themselves, namely for the secret that must be kept by the doctor. Similarly, it is difficult to formulate patient rights in detail, as well as obligations.

\section{Conclusion}

Health care is a relationship of trust between doctors and patients which in its development is called a therapeutic transaction or therapeutic agreement that is a transaction or agreement to determine therapy or provide healing services that are most appropriate for patients.

Every party that enters into an agreement must know and obey the principles of the agreement. Agreement principles are the moral and ethical foundation in making agreements. The principles of the agreement are the principle of freedom to enter into an agreement / principle of freedom of contract, principle of consensualism (conformity of will), principle of trust, principle of binding power, principle of equality of law, principle of balance, principle of legal certainty, moral principle, decency principle, and customary principle. Therapeutic agreements made will lead to rights and obligations. Doctors have responsibility for individuals and families, in addition to their professional responsibility for society. Likewise, patients who make agreements with doctors also have patient rights and obligations that must be carried out and can be accounted for.

\section{Bibliography}

Book:

Bander Johan Nasution, Hukum Kesehatan Pertanggungjawaban Dokter, Rineka Cipta,Jakarta, 2013.

Danny Wiradharma, Hukum Kedokteran, Binarupa Aksara, Jakarta, 1996.

Endang Kusuma Astuti, Transaksi Terapeutik Dalam Upaya Pelayanan Media Di Rumah Sakit, Citra Aditya Bakti, Bandung, 2009.

M. Achadiat Crisdiono, Pernik-Pernik Hukum Kedokteran, Melindungi Pasien dan Dokter, Widya Medika, jakarta, 1996.

Munandar Wahyudin Suganda, Hukum Kedokteran, Alfabeta, Bandung, 2017.

Titik Triwulan Tutik, Perlindungan Hukum Bagi Pasien, Prestasi Pustaka Publisher, Jakarta, 2010.

Veronica Komalawati, Peranan Informed Consent Dalam Transaksi Terapeutik, Citra Aditya Bakti, Bandung, 1999. 
Prof. Dr. Sarsintorini Putra, SH.,MH Anggraeni Endah Kusumaningrum : Existence of .....

\section{Law Journal:}

Anggraeni Endah Kusumaningrum, Penerapan Hak dan Kewajiban Pasien SebagaiKonsumen Dalam Pelayanan Medis, Fakultas Hukum Universitas 17 Agustus 1945, Semarang, Tanpa Tahun.

--------, Tinjauan Yuridis Hak dan Kewajiban Pasien Sebagai Konsumen Dalam Pelayanan Medis, Supremasi Hukum, Vol. 2 No. 1, Fakultas Hukum Universitas 17 Agustus 1945, Semarang, Juni 2013. 